\title{
MODEL PREDIKSI FINANCIAL DISTRESS PADA PERUSAHAAN MANUFAKTUR SEKTOR INDUSTRI BARANG DAN KONSUMSI
}

\author{
Herlina $^{1}$, Ahmad Ridho'í2 ${ }^{2}$ Anggie Erma Yunita ${ }^{3}$, Mega Puja Azhari $^{4}$, Ade Reynaldi Saputra $^{5}$ \\ 1,3,4Teknik Industri, Fakultas Teknik \\ Universitas 17 Agustus 1945 Surabaya, Surabaya, Indonesia \\ e-mail : 1herlina@untag-sby.ac.id, ${ }^{3}$ anggieyunita01@gmail.com, ${ }^{4}$ megapuja71@gmail.com \\ 2,5Teknik Elektro, Fakultas Teknik \\ Universitas 17 Agustus 1945 Surabaya, Surabaya, Indonesia \\ e-mail : 2ridhoi@untag-sby.ac.id, 5ade_rs@gmail.com
}

Diterima: 25 Oktober 2019. Disetujui : 25 Nopember 2019. Dipublikasikan : 31 Desember 2019

(C)2019 -TESJ Fakultas Teknik Universitas Maarif Hasyim Latif. Ini adalah artikel dengan

akses terbuka di bawah lisensi CC BY 4.0 (https://creativecommons.org/licenses/by/4.0/)

\begin{abstract}
ABSTRAK
Kesulitan keuangan (financial distress) adalah sebuah tahapan yang akan dilalui oleh sebuah perusahaan sebelum mengalami kebangkrutan. Dengan alasan tersebut maka kemampuan untuk memprediksi kesulitan keuangan dapat menjadi informasi yang bermanfaat bagi perusahaan maupun investor. Tujuan dari penelitian ini adalah untuk membandingkan tingkat akurasi dari model prediksi financial distress perusahaan manufaktur terbuka pada sektor industri barang konsumsi yang terdaftar pada Bursa Efek Indonesia menggunakan metode kecerdasan buatan serta algoritma evolusi. Metode yang digunakan untuk metode kecerdasan buatan adalah metode Support Vector Machines dan untuk model algoritma evolusi menggunakan metode Particle Swarm Optimization-Support Vector Machines. Tingkat akurasi dari masing-masing metode akan diukur dari prosentase misklasifikasi terkecil yang dihasilkan. Dari pengujian model menggunakan metode Support Vector Machines, didapatkan tingkat misklasifikasi terkecil sebesar $11,11 \%$ dengan menggunakan Kernel Linear dan untuk metode Particle Swarm Optimization-Support Vector Machines, didapatkan tingkat misklasifikasi terkecil sebesar 5,56\% dengan menggunakan Kernel $\mathrm{RBF}, \sigma=2$.
\end{abstract}

Kata kunci: financial distress, manufaktur, particle swarm optimization, support vector machines

\section{PENDAHULUAN}

Kondisi financial distress dapat dialami oleh semua perusahaan dan peluangnya menjadi lebih besar ketika terjadi krisis perekonomian di negara tempat operasional perusahaan tersebut. Kondisi financial distress yang dapat diprediksi sejak dini dapat memberikan keuntungan bagi perusahaan dikarenakan perusahaan tersebut dapat berusaha untuk memperbaiki kondisinya baik dari segi pemasaran ataupun produksi dengan menerapkan strategi-strategi khusus. Prediksi financial distress juga memberikan informasi yang bermanfaat bagi para penanam modal maupun pihak krditur sebagai bahan pertimbangan pengambilan keputusan. Karena manfaatnya bagi perusahaan dan berbagai pihak yang berkepentingan, maka penelitian mengenai prediksi financial distress menjadi topic penelitian yang menarik dan terus dikembangkan.

Penelitian dimulai dengan metode statistik yang pertama kali dilakukan oleh Altman pada tahun 1968 menggunakan metode Multiple
Discriminant Analysis (MDA). Metode statistik lainnya digunakan oleh Martin, 1997 yaitu Logistic Regression. Dari penelitian-penelitian menggunakan metode statistik dimana salah satu kekurangannya adalah masih terdapat asumsi mengenai kenormalan dan linearitas, kemudian mulai dikembangkan penelitian-penelitian menggunakan teknik data mining dan kecerdasan buatan, mulai dari Decision Tree, Artificial Neural Network, Support Vector Machines. Salah satu kelebihan dari teknik data mining adalah tidak adanya asumsi mengenai kenormalan dan linearitas seperti yang terdapat pada metode statistik. Teknik data mining menggunakan teknik klasifikasi yang akan menggolongkan data ke dalam kelasnya masing-masing, dalam hal ini adalah kelas perusahaan yang mengalami financial distress dan kelas perusahaan yang tidak mengalami financial distress.

Pada penelitian terdahulu (Shin, Lee, \& Kim, 2005) mengemukakan bahwa Support Vector Machines (SVM) merupakan metode klasifikasi yang cukup handal untuk kasus klasifikasi. 
Penggunaan metode SVM untuk prediksi financial distress yang telah diteliti oleh Shin (Shin et al., 2005) diterapkan pada perusahaan di Korea Selatan dengan hasil yang baik. Demikian juga Ding (Ding, Song, \& Zen, 2008) menerapkan untuk perusahaan di Cina dan juga mendapatkan hasil yang baik.

SVM adalah sebuah algoritma yang diusulkan oleh Vapnik pada tahun 1995. SVM tergolong metode klasifikasi baru dan telah banyak dijadikan metode dalam sejumlah penelitian, seperti pattern recognition, regresi, dan estimasi. Menutut Santosa (Santosa, 2007), SVM berada dalam satu kelas dengan ANN (Artificial Neural Network) tetapi dalam banyak implementasi terbukti bahwa SVM memberikan hasil yang lebih baik daripada ANN dalam hal solusi yang dicapai. ANN menemukan solusi yang berupa lokal optimal sedangkan SVM menemukan solusi yang global optimal. Metode SVM akan memetakan data input ke dalam ruang berdimensi tinggi yang nantinya akan didapatkan fungsi pemisah yang linear yang akan memisahkan data ke dalam kelas yang berbeda. SVM menggunakan masukan atau input dari data training untuk menemukan fungsi pemisah (klasifier/hyperplane) terbaik diantara fungsi yang tidak terbatas jumlahnya untuk memisahkan dua macam obyek. Hyperplane terbaik didapatkan dengan memaksimalkan margin atau jarak diantara dua set obyek dari kelas yang berbeda. SVM dapat diterapkan pada data yang bersifat linear maupun non-linear. Untuk kasus klasifikasi, dimana datanya tidak linear dapat menggunakan metode Kernel.

Chen (Chen \& Chen, 2010) mengaplikasikan PSO pada SVM dan melakukan penelitian pada perusahaan di Taiwan menggunakan rasio-rasio keuangan. Hasil dari penelitiannya menyatakan bahwa PSO-SVM dapat meningkatkan akurasi dari model prediksi financial distress. Particle swarm optimization (PSO) diusulkan oleh Kennedy dan Eberhart pada tahun 1995. PSO didasarkan pada perilaku sekawanan burung atau ikan. Algoritma PSO meniru perilaku sosial organisme ini yang terdiri dari tindakan individu dan pengaruh dari individu-individu lain dalam suatu kelompok (Santosa \& Willy, 2011).

Penelitian ini akan membuat model prediksi financial distress untuk perusahaan manufaktur terbuka yang terdaftar pada Bursa Efek Indonesia khusus untuk sektor industri barang dan konsumsi menggunakan metode Support Vector Machines (SVM) dan Particle Swarm Optimization-Support Vector Machines (PSO-SVM).

\section{METODE PENELITIAN}

Penelitian ini dilaksanakan dengan tahapan sebagai berikut:

1. Langkah pertama adalah membuat algoritma metode Support Vector Machine (SVM), dan Particle Swarm Optimization-Support Vector Machines (PSO-SVM).

2. Melakukan uji validasi terhadap metode PSOSVM.

3. Menetapkan data

Penelitian ini menggunakan sampel perusahaan manufaktur terbuka sektor industri barang dan konsumsi yang terdaftar pada Bursa Efek Indonesia (BEI). Perusahaan yang menjadi obyek amatan dalam penelitian ini adalah perusahaan yang memiliki laporan keuangan lengkap. Laporan keuangan yang akan digunakan dalam penelitian ini adalah laporan keuangan tahunan pada periode 2014 sampai dengan 2017. Data laporan keuangan perusahaan-perusahaan amatan dapat diperoleh melalui Indonesia Capital Market Directory (ICMD). Data yang akan diberi label sebagai perusahaan yang mengalami financial distress adalah data untuk tahun 2017 dengan label -1 untuk perusahaan yang mengalami financial distress dan label 1 untuk perusahaan yang tidak mengalami financial distress. Kriteria yang digunakan untuk menentukan perusahaan yang mengalami financial distress adalah jika perusahaan tersebut dalam laporan keuangannya memenuhi salah satu atau lebih dari kriteria berikut (Setyowati, 2009):

a. Modal kerja (working capital)negatif

b. Laba operasi negatif

c. Laba bersih negatif

4. Pemilihan variable sebagai indikator financial distress.

5. Transformasi Data

Sebelum nilai dari variabel-variabel tersebut dimasukkan ke dalam model, perlu dilakukan transformasi data atau yang disebut sebagai data preprocessing. Transformasi data ini perlu dilakukan untuk membuat rentang data yang sebelumnya tidak sama untuk setiap variabel menjadi seragam sesuai dengan rentang yang telah ditentukan. Teknik yang akan digunakan dalam melakukan transformasi data dalam penelitian ini adalah scaling. Scaling adalah prosedur merubah data sehingga berada dalam skala tertentu. Dalam penelitian ini akan digunakan skala $(-1,1)$, dimana dalam hal ini, batas bawah (BB) adalah -1 dan batas atas (BA) adalah 1. Jika nilai maksimum tiap kolom (variabel) adalah Xmax dan nilai minimumnya adalah Xmin, untuk mengubah data ke skala baru, dapat digunakan rumus (Santosa, 2007):

$$
\hat{x}=\frac{X-X \min }{X \max -X \min } x(B A-B B)+B B
$$


6. Penentuan Data Training dan Data Testing Akan dipilih secara random dataset sebagai training data dan testing data. Rasio antara training data dengan testing data yang akan digunakan adalah 2:1. Random sampling akan dilakukan sebanyak 10 kali dan nantinya akan dihitung rata-rata nilai akurasinya.

7. Membangun model klasifikasi

Langkah berikutnya adalah membuat model prediksi financial distress menggunakan metode Support Vector Machine (SVM), dan Particle Swarm Optimization-Support Vector Machines (PSO-SVM).

8. Membandingkan hasil dari SVM dan PSO-SVM dari segi tingkat akurasi.

\section{HASIL DAN PEMBAHASAN}

Jumlah perusahaan manufaktur terbuka di Indonesia di sektor industri barang konsumsi yang memiliki laporan keuangan secara lengkap selama periode 2014 sampai dengan 2017 ada sebanyak 26 perusahaan.

Data yang akan diberi label sebagai perusahaan yang mengalami financial distress adalah data untuk tahun 2017 dengan label -1 untuk perusahaan yang mengalami financial distress dan label 1 untuk perusahaan yang tidak mengalami financial distress.

Pada tahun 2017, jumlah perusahaan yang mengalami financial distress (kelas negatif) sebanyak 7 perusahaan sedangkan jumlah perusahaan yang tidak mengalami financial distress (kelas positif) sebanyak 19 perusahaan.

Variabel-variabel yang akan digunakan pada penelitian ini meliputi variabel keuangan dengan beberapa rasio keuangan, antara lain rasio likuiditas, rasio solvabilitas, rasio profitabilitas dan rasio investor. Daftar variabel beserta rumusnya dapat dilihat pada Tabel 1.

Likuiditas perusahaan menggambarkan kemampuan perusahaan dalam memenuhi kewajiban jangka pendeknya dan juga untuk mengukur efisiensi penggunaan aktiva lancar.
Rasio solvabilitas digunakan untuk mengukur kemampuan perusahaan dalam memenuhi kewajiban jangka panjang dan juga untuk mengukur tingkat perlindungan yang diberikan perusahaan kepada para kreditor jangka panjang. Rasio investor merupakan rasio-rasio profitabilitas tertentu yang menjadi perhatian para investor.

Working Capital-to-total assets, merupakan perbandingan antara selisih total aktiva lancar dan hutang lancar dengan total aktiva. Rasio ini digunakan untuk mengukur likuiditas dari perusahaan. Current Ratio, merupakan perbandingan antara aktiva lancar dengan hutang lancar. Rasio ini digunakan untuk mengukur sejauh mana perusahaan mampu membayar hutanghutang jangka pendek.

Debt-to-equity, merupakan perbandingan antara total hutang (debt) dengan total aktiva (asset). Rasio ini memberikan gambaran mengenai struktur modal perusahaan untuk melihat tingkat resiko tidak tertagihnya suatu hutang. Leverage ratio, merupakan perbandingan antara total hutang (liabilities) dan total aktiva (assets). Rasio ini digunakan untuk mengukur seberapa besar total asset yang dibiayai oleh total hutang yang ada. Semakin tinggi rasio ini maka semakin besar resiko yang dihadapi perusahaan.

Gross profit margin, merupakan perbandingan antara laba kotor dengan penjualan. Rasio ini mengukur efisiensi produksi dan penentuan harga jual. Net profit margin, merupakan perbandingan antara laba bersih dengan penjualan. Rasio ini digunakan untuk mengukur seberapa besar proporsi keuntungan bersih yang diterima perusahaan yang berasal dari penjualan. Operating Profit margin, merupakan perbandingan antara operating income dengan penjualan. Rasio ini merupakan salah satu rasio profitabilitas yang digunakan untuk mengukur kemampuan perusahaan dalam menghasilkan pendapatan untuk mempertahankan kelangsungan usahanya. Return On Equity (ROE), merupakan perbandingan antara laba bersih dengan total ekuitas. Rasio ini mengukur kemampuan perusahaan dalam menghasilkan laba yang akan

Tabel 1. Daftar Variabe

\begin{tabular}{c|l|l}
\hline \multicolumn{1}{c|}{ Kriteria } & \multicolumn{1}{|c}{ Sub Kriteria } & \multicolumn{1}{c}{ Deskripsi } \\
\hline \multirow{2}{*}{ Rasio Likuiditas } & Working Capital-to-Total Asset & (Current Assets - Current Liabilities) / Total Assets \\
\cline { 2 - 3 } & Current Ratio & Current Assets / Current Liabilities \\
\hline Rasio Solvabilitas & Debt-to-Equity & Total Liabilities / Total Equity \\
\cline { 2 - 3 } & Leverage Ratio & Total Liablities / Total Assets \\
\hline \multirow{2}{*}{ Rasio Profitabilitas } & Gross Profit Margin & Gross Profit / Sales \\
\cline { 2 - 3 } & Net Profit Margin & Net Income / Sales \\
\cline { 2 - 3 } & Operating Profit Margin & Operating income / Sales \\
\cline { 2 - 3 } & ROE & Net Income / Total Equity \\
\cline { 2 - 3 } & ROA & Net Income / Total Assets \\
\hline Rasio Investor & EPS & $\begin{array}{l}\text { (Laba bersih - dividen saham istimewa) / jumlah lembar saham biasa } \\
\text { yang beredar }\end{array}$ \\
\cline { 2 - 3 } & Book Value per Share & $\begin{array}{l}\text { (Total Stockholders'Equity - Preferred Stock) / Jumlah lembar saham } \\
\text { biasa yang beredar }\end{array}$ \\
\hline
\end{tabular}


bermanfaat bagi para pemegang saham. Return On Asset (ROA), merupakan perbandingan antara laba bersih dengan total aktiva (assets). Rasio ini mengukur kemampuan perusahaan dalam memanfaatkan aktivanya untuk memperoleh laba.

Earning per Share (EPS), merupakan perbandingan antara selisih dari laba bersih dan deviden saham istimewa dengan jumlah lembar saham yang beredar. Rasio ini digunakan untuk mengukur jumlah laba yang menjadi hak untuk setiap pemegang satu lembar saham biasa. Book value per share (BV), merupakan perbandingan antara selisih ekuitas pemegang saham dan preferred stock dengan jumlah lembar saham biasa yang beredar. Rasio ini menunjukkan jumlah stockholders'equity yang berkaitan dengan setiap lembar saham yang beredar.

Model prediksi financial distress yang digunakan dalam penelitian ini, yaitu Support Vector Machines menggunakan teknik data mining, dimana data mining atau disebut juga knowledge discovery in database adalah kegiatan yang meliputi pengumpulan dan pemakaian data historis untuk menemukan keteraturan, pola atau hubungan dalam dataset yang berukuran besar (Santosa, 2007). Berdasarkan data training yang digunakan dalam model, akan ditemukan pola untuk melakukan prediksi nilai label dari data testing. Sehingga untuk mendapatkan hasil prediksi apakah sebuah perusahaan mengalami financial distress atau tidak dalam model penelitian ini, tidak diperlukan nilai parameter khusus dari rasio finansial yang digunakan sebagai indikator financial distress. Melalui sejumlah data training yang digunakan, ketika dimasukkan data baru untuk diuji, maka label prediksi dari data uji tersebut akan didapat dengan membaca pola dari sejumlah data training yang telah digunakan untuk men-training model.

Pada penelitian ini, perbandingan antara data testing dan data training yang akan digunakan sebesar 2:1. Menurut penelitian Nisa (Nisa, Santosa, \& Wiratno, 2013), dataset yang seimbang akan memberikan tingkat akurasi yang lebih besar daripada dataset yang tidak seimbang antara kelas positif dan kelas negatif. Karena dataset antara kelas positif dan kelas negatif jumlahnya tidak seimbang, maka sebagai data training dan data testing akan dibuat seimbang dengan mengambil sebagian data kelas positif secara acak sebanyak jumlah dataset kelas negatif.

Data training yang digunakan dalam penelitian ini sebanyak 6 perusahan dari kelas positif dan 6 perusahaan dari kelas negatif. Data testing yang digunakan dalam penelitian ini sebanyak 3 perusahaan dari kelas positif dan 3 perusahaan dari kelas negatif.

Data training dan data testing yang telah ditentukan akan diuji secara komputasi dengan software MATLAB menggunakan metode SVM standard dan PSO-SVM. Jenis Kernel yang akan digunakan dalam penelitian ini adalah linear, polynomial dengan derajat 4, dan RBF dengan $\sigma=2$. Pengujian dilakukan terhadap tiga kombinasi yang berbeda dari data training dan data testing. Hasil rata-rata pengujian model dengan metode SVM dapat dilihat pada Tabel 2 dan untuk metode PSOSVM dapat dilihat pada Tabel 3.

Tabel 2. Hasil pengujian dataset menggunakan SVM standar

\begin{tabular}{l|c}
\multicolumn{1}{c|}{ Kernel } & Misklasifikasi (\%) \\
\hline Linear, C=100 & 11,11 \\
\hline Polynomial derajat 4, C=100 & 33.33 \\
\hline RBF, $\sigma=2, C=100$ & 16,67 \\
\hline
\end{tabular}

Dataset yang telah diuji dengan SVM standar akan dibandingkan hasilnya dengan pengujian menggunakan PSO-SVM. Dataset yang digunakan untuk PSO-SVM sama dengan dataset yang digunakan pada pengujian dengan SVM standar. Jenis Kernel yang digunakan juga sama yaitu linear, polynomial dengan derajat 4, dan RBF dengan $\sigma=2$, dengan nilai $\mathrm{C}=10$, jumlah partikel $\mathrm{N}=20$, konstanta $\mathrm{c} 1=1, \mathrm{c} 2=5$.

Tabel 3. Hasil pengujian dataset menggunakan PSO-SVM

\begin{tabular}{l|c}
\multicolumn{1}{c|}{ Kernel } & Misklasifikasi (\%) \\
\hline Linear & 38,87 \\
\hline Polynomial derajat 4 & 50 \\
\hline RBF, $\sigma=2$ & 5,56 \\
\hline
\end{tabular}

\section{PENUTUP}

Tingkat misklasifikasi prediksi financial distress menggunakan Metode Support Vector Machines (SVM) yang terendah sebesar 11,11\% dengan menggunakan jenis Kernel Linear.

Tingkat misklasifikasi prediksi financial distress menggunakan Metode Particle Swarm Optimization - Support Vector Machines (PSO-SVM) yang terendah sebesar 5,56\% dengan menggunakan jenis Kernel RBF, $\sigma=2$.

Pemilihan data perusahaan manufaktur dipilih berdasarkan sub-sektor tertentu untuk semua sector yang ada di Bursa Efek Indonesia.

\section{UCAPAN TERIMA KASIH}

Ucapan terima kasih disampaikan kepada Yayasan Perguruan Tinggi 17 Agustus 1945 Surabaya atas pendanaan terhadap penelitian ini.

\section{DAFTAR PUSTAKA}

Altman, E. I. (1968). Financial ratios, discriminant analysis and the prediction of corporate 
bankruptcy. The Journal of Finance, 23(4), 589-609.

Chen, B.-T., \& Chen, M.-Y. (2010). Applying particles swarm optimization for support vector machines on predicting company financial crisis. International Conference on Business and Economics Research, 1. Kuala Lumpur, Malaysia.

Ding, Y., Song, X., \& Zen, Y. (2008). Forecasting financial condition of Chinese listed companies based on support vector machine. Expert Systems with Applications, 34(4), 3081-3089.

Martin, D. (1977). Early warning of bank failure: A logit regression approach. Journal of Banking \& Finance, 1(3), 249-276.

Min, J. H., \& Lee, Y.-C. (2005). Bankruptcy prediction using support vector machine with optimal choice of kernel function parameters. Expert Systems with Applications, 28(4), 603-614.

Nisa, U. Z., Santosa, B., \& Wiratno, S. E. (2013). Model Prediksi Finansial Distress Pada
Perusahaan Manufaktur Go Public di Indonesia. Prosiding Seminar Nasional Manajemen Teknologi XVIII, 1-8.

Ross, S. A., Westerfield, R., \& Jordan, B. D. (2008). Fundamentals of corporate finance. New York: Tata McGraw-Hill Education.

Santosa, B. (2007). Data Mining: Teknik Pemanfaatan Data untuk Keperluan Bisnis. Yogyakarta: Graha Ilmu.

Santosa, B., \& Willy, P. (2011). Metoda Metaheuristik konsep dan implementasi. Surabaya: Guna Widya.

Setyowati, W. (2009). Strategi Manajemen sebagai Faktor Mitigasi Terhadap Penerimaan Opini Going Concern Studi Empirik pada Perusahaan Manufaktur di Indonesia. Universitas Diponegoro.

Shin, K.-S., Lee, T. S., \& Kim, H. (2005). An application of support vector machines in bankruptcy prediction model. Expert Systems with Applications, 28(1), 127-135. 
Herlina, dkk / Teknika : Engineering and Sains Journal, Vol. 3, No.2, Desember 2019, 5xx-yy

Halaman ini sengaja dikosongkan 